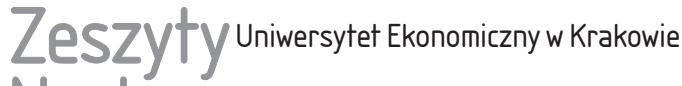 Naukowe
}

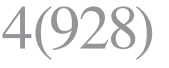

ISSN 1898-6447

Zesz. Nauk. UEK, 2014; 4 (928): 71-83 DOI: $10.15678 /$ ZNUEK.2014.0928.0406

Joanna Wyrobek

Katedra Finansów Przedsiębiorstw

Uniwersytet Ekonomiczny w Krakowie

\section{Wpływ zjawisk window dressing i kreatywnej ksiegowości na obraz sprawozdania finansowego przedsiębiorstwa}

\section{Streszczenie}

Celem artykułu było przedstawienie popularnych w 2013 r. technik poprawiania wizerunku przedsiębiorstwa w sprawozdaniu finansowym jednostki. Publikacja została oparta na wywiadach z przedsiębiorcami oraz analizie literatury z zakresu finansów, uzupełniono ją o analizę wybranych zmian w ustawodawstwie polskim mających na celu przeciwdziałanie wybranym praktykom.

Słowa kluczowe: kreatywna księgowość, sprawozdawczość finansowa, rachunkowość, window dressing, analiza finansowa, przestępczość finansowa.

\section{Formy upiększania wizerunku przedsiębiorstwa}

Zgodnie z ustawą o rachunkowości i normą numer 1 Krajowej Rady Biegłych Rewidentów sprawozdanie finansowe ma przedstawiać rzetelnie i jasno sytuację majątkową, finansową oraz wynik finansowy podmiotu gospodarczego. W rzeczywistości jednak sprawozdanie finansowe często podlega manipulacji. Wśród manipulacji wyróżnić można dozwolone techniki finansowe, rozliczania kosztów w czasie, renegocjowanie umów itd. Zaliczane są one do praktyki gospodarczej i nie mają swojej nazwy. Inne transakcje mają zwykle charakter jednora- 
zowy i są wykonywane przed końcem roku obrotowego. Nie łamią one zwykle zasad rachunkowości, a ich celem jest pewne upiększenie wizerunku jednostki. Techniki te nazywa się window dressingiem.

Druga grupa technik to techniki nazywane kreatywną rachunkowością. Są to działania pozornie zgodne z zasadami i regulacjami rachunkowości, ale w rzeczywistości są z nimi sprzeczne, gdyż odbiegają od intencji, jakie te regulacje miały realizować. Techniki kreatywnej rachunkowości często wykorzystują także luki w prawie.

Oprócz window dressingu i kreatywnej rachunkowości kreowanie określonego obrazu przedsiębiorstwa może wykorzystywać techniki całkowicie nielegalne, łamiące zasady, reguły i intencje rachunkowości, jak i prawo wiążące się z przestępczością gospodarczą.

Celem niniejszej pracy jest opisanie technik (należących do powyższych grup) znanych w polskiej literaturze (a zatem potencjalnie stosowanych przez polskie przedsiębiorstwa), a także empiryczne (poprzez badania ankietowe) sprawdzenie popularności wybranych metod. W szczególności podjęto próbę zbadania, jak często dochodzi do modyfikowania obrazu sytuacji finansowej przedsiębiorstwa (poprzez zmiany wybranych elementów sprawozdania finansowego) oraz które techniki są najpopularniejsze.

\section{Korzyści z ,upiększania” sprawozdania finansowego}

Firmy chcą się korzystniej przedstawiać z wielu powodów. Między innymi pozytywny obraz jednostki zniechęca do składania wniosku o upadłość wierzycieli jednostki (nawet jeżeli posiadają niezapłacone na czas faktury), banki nie mają podstawy do rozwiązania umowy kredytowej, klienci nie obawiają się niewywiązania się podmiotu z umów, a udziałowcy nie będą się szerzej interesowali decyzjami zarządu i nie będą ingerowali w działania zarządu. W przypadku spółek giełdowych, korzystny obraz sprawozdania finansowego będzie skłaniał rynek do wysokiej wyceny jednostki i nie dojdzie do spadku kursu akcji, który niekorzystny byłby tak dla zarządu, udziałowców, jak i posiadaczy akcji. Brak negatywnych sygnałów w sprawozdaniu finansowym działa uspokajająco także na dostawców.

W przypadku spółek zależnych słabe wyniki finansowe są podstawą do pozytywnej oceny pracowników dokonywanej w ramach systemu controllingu i przyznawania im ewentualnych premii. $Z$ kolei w przypadku przedsiębiorstw wystawionych na sprzedaż chodzi o podniesienie ich wartości i ceny sprzedaży. 


\section{Popularne techniki ,upiększania” sprawozdań finansowych}

Legalnych i nielegalnych technik manipulowania obrazem jednostki jest bardzo wiele, przy czym niekiedy trudno zdecydować, gdzie kończą się techniki upiększania, a zaczyna oszukiwanie i wykorzystywanie osób trzecich (pracowników, dostawców, klientów, władz podatkowych) w celu zdobycia korzyści dla przedsiębiorstwa, zarządu, właściciela. W publikacji opisano techniki nastawione bezpośrednio na „upiększenie” sprawozdania finansowego w odróżnieniu od technik wyprowadzania pieniędzy z jednostki lub uchylenia się i unikania opodatkowania.

Jednorazowe techniki majace poprawić wskaźniki finansowe, typowy window dressing

$\mathrm{Na}$ koniec roku, przed zamknięciem ksiąg rachunkowych dość często pojawia się konieczność poprawy płynności jednostki, aby obliczone na podstawie bilansu wskaźniki płynności były odpowiednio wysokie. Po odpowiedniej decyzji zarządu i renegocjowaniu umów z partnerami jednostka może w tym celu przeklasyfikować część należności i inwestycji krótkoterminowych na krótkookresowe, a część zobowiązań krótkookresowych (część kredytu zaplanowana do spłaty w ciągu najbliższego roku) na długookresowe, co podniesie wskaźniki płynności. Inną możliwość daje zaciągnięcie długookresowej pożyczki.

W przypadku, gdy na majątku obrotowym lub trwałym ustanowione są zabezpieczenia, firma może nie podejmować dużych starań, aby ten fakt wyraźnie akcentować. To z kolei powoduje, że wskaźniki płynności będą obliczane z uwzględnieniem tych elementów, pomimo ich niskiej rzeczywistej płynności (nie można upłynnić zabezpieczenia kredytu).

W przypadku jednostek stosujących MSR jednostka może mało precyzyjnie prezentować elementy sprawozdania (na przykład pozycję rachunku zysków i strat: inne całkowite dochody i jej składowe) oraz stosować nieprecyzyjne i zróżnicowane nazwy różnych elementów sprawozdania [Szychta 2012, s. 82], co skutecznie utrudni interpretację sprawozdań i porównywalność danych wobec konkurencji (płynności, rentowności).

Podnoszenie przychodów ze sprzedaży i wielkości obrotu

Inną techniką poprawy wyglądu sprawozdania finansowego może być uznanie większego niż być powinno stopnia realizacji umów, co zwiększy przychody ze sprzedaży [Hołda 2006, Gut 2006, s. 96]. Inną opcją podniesienia przychodów ze sprzedaży jest wykorzystanie względnej subiektywności klasyfikacji, co zalicza się do podstawowej działalności jednostki, a co do pozostałych przychodów operacyjnych [Wąsowski 2010a]. Prostą i legalną techniką podnoszenia sprzedaży jest także sprzedaż bezzyskowa na przykład jabłek lub pomarańczy [Jones 2011]. 
Wzrost obrotu jednostka może także uzyskać w efekcie wykupu innej jednostki, w tym również wykupu lewarowanego [Fridson i Alvarez 2011]). Może się także zdarzyć, że do przychodów ze sprzedaży zaliczone zostaną pożyczki (traktowane jako przedpłaty) lub dotacje [Jones 2011].

Przedsiębiorstwa mogą także wymieniać się produktami (np. swap częstotliwości) i działania te klasyfikować jako sprzedaż, szczególnie w przypadku produktów niechodliwych. Jeżeli zaś taka sprzedaż nie ogranicza się do dwóch firm tylko do wielu (co utrudnia kontroli skarbowej i podatkowej wykrycie), gdzie pojawia się firma słup (założona na bezdomnego), która ma upaść po zawarciu transakcji i całość jest nakierowana na wyłudzenie zwrotu podatku VAT, to taki proceder nazywa się przestępstwem karuzelowym ${ }^{1}$.

Kiedy te techniki są niewystarczające, zarządowi pozostaje m.in. leasing zwrotny, czyli sprzedaż majątku niezbędnego do funkcjonowania jednostki i wyleasingowanie go od kupca. Sprzedaż może dotyczyć środków trwałych, budynku, gruntu, działki.

\section{Obniżanie kosztów}

Jeżeli firma zdecyduje się obniżyć koszty, to ma do dyspozycji cały arsenał technik. Należą do nich: rozwiązanie rezerw, obniżenie podatku dochodowego (przez tzw. optymalizację podatkową, czyli wykorzystanie luk w systemie prawa), kapitalizację kosztów (na przykład stwierdzenie, że remont nie został zakończony, wliczanie odsetek w koszt realizowanych inwestycji, jeżeli kredyt finansuje tę inwestycję, kapitalizowanie kosztów rozwoju oprogramowania, kapitalizowanie niezbyt zachęcających prac badawczych i rozwojowych, kapitalizowanie jako koszty rozwijania potencjału firmy wynagrodzeń techników utrzymujących w sprawności systemy informatyczne czy komunikacyjne [Jones 2011], kapitalizowanie jako kosztów przygotowania nowych projektów kosztów utrzymania majątku, który firma chce wyleasingować (ale na razie nie znalazła chętnych), zwiększenie wartości końcowego stanu zapasów (co zmniejsza koszt sprzedanych wyrobów, a to poprzez zmianę metody kalkulacji kosztu wytworzenia i wyceny zapasów), wydłużenie życia aktywów (spowolnienie amortyzacji albo wycena w dół odnoszona na kapitał podstawowy, a nie na wynik finansowy) [Kutera 2008, s. 136]. W końcu też firma nie będzie aktualizowała w dół wartości nieudanych inwestycji, nieudanych prac badawczych, starych zapasów itd. [Wąsowski 2010b, s. 87].

Jednostka może także starać się w pełni wykorzystać możliwość odniesienia niektórych ze strat bezpośrednio na kapitał własny, z pominięciem rachunku

\footnotetext{
${ }^{1}$ Przestępstwa karuzelowe na prętach stalowych w Polsce stały się tak powszechne, że w 2013 r. rząd podjął próbę ukrócenia tego typu przestępstw, stosując tzw. odwrotne obciążenie, czyli obciążając nabywcę obowiązkiem odprowadzenia podatku VAT.
} 
zysków i strat (skutki przeszacowania (aktualizacji wyceny) wartości środków trwałych i inwestycji długoterminowych, koszty z tytułu organizacji i rozszerzenia skali działania spółki akcyjnej, wpływ zmian rachunkowości na kapitał własny, wpływ błędów podstawowych, spowodowanych zaszłościami lat ubiegłych, odnoszonych na kapitał własny, naliczenie odroczonego podatku dochodowego rozliczanego z kapitałem własnym od różnic przejściowych).

\section{Zwiększanie wartości aktywów}

Kolejna grupa technik dotyczy zwiększania wartości aktywów. Przedsiębiorstwa dokonują tego w sztuczny sposób, wykorzystując możliwości, jakie daje dobre imię firmy (goodwill), wartość marek i innych aktywów niematerialnych, gdyż ich wycena opiera się na wycenie eksperta. Firmy bardzo często dążą do maksymalnej wyceny dobrego imienia firmy, aby po ustaleniu ceny za jaką mogą przejąć inną jednostkę maksymalnie dużo z tej ceny przypisać na goodwill, a minimalną ilość na aktywa rzeczowe. Dzięki temu przy sprzedaży przejętych aktywów rzeczowych gwarantują sobie zysk z takiej transakcji, a goodwill albo podnosi trwale wartość aktywów, albo pozwala na znaczące obniżenie podstawy opodatkowania, jeżeli w danym kraju podlega amortyzacji.

\section{Zmniejszanie poziomu zadłużenia}

Aby obniżyć zadłużenie, przedsiębiorstwo może albo korzystać z finansowania pozabilansowego albo dokonać (albo zachęcać do) konwersji długu na kapitał własny. Finansowanie pozabilansowe często udaje się stworzyć w sytuacji, gdy firma posiada udziały w innej jednostce (albo inne powiązania), ale nie jest to jeszcze jednostka zależna (ani na podstawie ilości posiadanych głosów, ani innych prawnych kryteriów definiujących spółkę zależną, których nie bierze się pod uwagę). Niekiedy spółka dominująca może skłonić taką jednostkę, której udziały posiada do wzięcia kredytów na siebie i cichego finansowania spółki dominującej (np. odsprzedaż aktywów za obniżoną ceną) albo do odkupu niepotrzebnych aktywów. Inny wariant to udzielenie gwarancji spółce dominującej, co pozwala jej zaciągnąć kredyt albo podpisać długookresowe umowy najmu.

Kolejna możliwość to emisja obligacji z opcją ,put”, co daje nabywcy po kilku latach możliwość zażądania od emitenta ich wykupu - jednak obligacje dają też możliwość ich konwersji na akcje, a zarząd zadba o to, aby ich ceny szybko rosły. W efekcie zachęceni wzrostem cen akcji obligatariusze zdecydują się na konwersję obligacji na akcje zamiast na ich wykup. Czasami (w przypadku dużej firmy z dużym kredytem) firmie może udać się nakłonić bank do konwersji długu na kapitał własny.

Krótkookresową strategią może być także zadeklarowanie dopłat do kapitału własnego i zaksięgowanie podwyższenia kapitału, a nie wniesienie wspomnianych wpłat albo wniesienie nieskuteczne z powodu niedopełnienia procedur prawnych 
związanych z takim podniesieniem kapitału własnego (rejestracja w sądzie, dowody wpłaty, udokumentowanie przez notariusza itd.).

Podnoszenie salda przepływów pieniężnych netto z działalności operacyjnej

„Upiększanie” można także zastosować dla rachunku przepływów pieniężnych. Co prawda przepływy pieniężne rzadziej są szacowane, a częściej wynikają z konkretnych i zakończonych transakcji, ale i tutaj bywają wyjątki. Ponadto w przypadku cash flow może nie chodzić jedynie o modyfikowanie wartości, ale także o przesunięcia w czasie przepływów pomiędzy latami lub o przesuwanie przepływów tak, aby maksymalnie zwiększyć saldo działalności operacyjnej, które najbardziej interesuje analityków. Firmy zatem będą starały się umieścić w przepływach operacyjnych zyski gotówkowe związane z niekontynuowaną działalnością (np. sprzedaż aktywów), zawężając definicję aktywów trwałych, z kolei straty gotówkowe będą chciały przenosić do działalności operacyjnej, poszerzając definicję aktywów trwałych.

Manipulowanie obrazem finansów firmy dzięki szeregowi spółek nadrzędnych lub zależnych

Dla kreatywnych przedsiębiorców ogromne możliwości manipulowania rentownością przedsiębiorstw dają „łańcuszki” kolejnych przedsiębiorstw kontrolujących inne przedsiębiorstwa, szczególnie jeżeli część firm z takiego „łańcuszka” zarejestrowana jest w rajach podatkowych (skąd trudniej uzyskać informacje o strukturze akcjonariatu). Dostępne są tutaj różne możliwości: wzajemne pożyczki, lokaty, stosowanie cen transferowych, opłaty za pozorne doradztwo, wzajemne aporty o źle określonej wartości (zaniżone lub zawyżone), przenoszenie nadgodzin pomiędzy przedsiębiorstwami (pracownicy jednej jednostki nadgodziny wykonują dla innej jednostki holdingu, wynajmy, dzierżawy) [Kaczmarek 2010].

Inne techniki krótkookresowej poprawy wizerunku firmy

Warto także wspomnieć o możliwości sprzedaży działki i budynków należących do firmy, jeżeli znajduje się w centrum miasta i zmiana lokalizacji na tereny dużo tańsze. Jednorazowy zysk na takiej transakcji także poprawia „obraz” rentowności jednostki.

\section{Skala ,upiększania” sprawozdań finansowych w Polsce}

Tabela 1 przedstawia wyniki badań ankietowych (w formie wywiadu) przeprowadzonych na próbie 23 przedsiębiorstw, z których część znajdowała się w bardzo złej sytuacji gospodarczej. Przedsiębiorstwa pochodziły z województw małopol- 
skiego i podkarpackiego, odpowiedzi udzielali pracownicy bezpośrednio ankietującemu po zapewnieniu całkowitej anonimowości badania. Pozyskanie odpowiedzi na zadawane pytania nie było łatwe, większość osób odmawiała udzielania odpowiedzi, tłumacząc się brakiem czasu lub tym, że nie chcieli ujawniać informacji o przedsiębiorstwie. Dlatego jakkolwiek tak mała próba nie może zostać uznana za reprezentatywną, to jednak jest efektem żmudnej pracy i na zasygnalizowaniu, że pewne zjawiska mogą być stosunkowo powszechne w gospodarce polskiej.

Celem badania było sprawdzenie jak często w przedsiębiorstwach stosowane są opisane wcześniej techniki. Warto jednak zaznaczyć, że wiele z opisanych czynności powszechnie stosuje się w rachunkowości (np. aktualizację należności) i jedynie niektórym można przypisać funkcję window dressingu.

Tabela 1. Wyniki ankiety badającej powszechność wybranych technik upiększania sprawozdań finansowych, lata 2010-2012, próba 23 przedsiębiorstw

\begin{tabular}{|l|c|}
\hline \multicolumn{1}{|c|}{ Wyszczególnienie } & Procent \\
\hline 1. Wielkość firmy & 39,1 \\
\hline małe (do 50 osób) & 13,0 \\
\hline średnie (powyżej 50 do 250) & 43,5 \\
\hline duże (powyżej 250 osób) & 13,0 \\
\hline 2. Wiek firmy & 21,7 \\
\hline do 5 lat & 65,2 \\
\hline powyżej 5 i do 10 lat & 39,1 \\
\hline więcej od 10 lat & 26,1 \\
\hline 3. Kategoria pracownika & 26,1 \\
\hline pracownik działu finansowego & 13,0 \\
\hline kierownik & 0,0 \\
\hline właściciel & 78,3 \\
\hline pracownik biura rachunkowego, który prowadzi rachunkowość przedsiębiorstwa \\
\hline inny & 21,7 \\
\hline 4. Czy w jednostce zdarzyło się renegocjować terminy płatności z klientami? \\
\hline tak & 34,8 \\
\hline nie & 47,8 \\
\hline 5. Czy w jednostce zdarzyło się renegocjować terminy płatności z dostawcami? \\
\hline tak & 56,5 \\
\hline nie & 43,5 \\
\hline 6. Czy jednostce zdarzyło się renegocjować terminy spłaty kredytu z bankiem? \\
\hline tak & \\
\hline nie & \\
\hline nie braliśmy kredytu & \\
\hline
\end{tabular}


cd. tabeli 1

\begin{tabular}{|c|c|}
\hline Wyszczególnienie & Procent \\
\hline \multicolumn{2}{|l|}{ 7. Czy w jednostce zdarzyło się renegocjować terminy spłaty pożyczek? } \\
\hline tak & 30,4 \\
\hline nie & 26,1 \\
\hline nie zaciągaliśmy nigdy pożyczek & 43,5 \\
\hline \multicolumn{2}{|c|}{ 8. Czy zdarzyło się zaciągnąć kredyt długookresowy aby podnieść płynność finansową? } \\
\hline tak & 17,4 \\
\hline nie & 82,6 \\
\hline \multicolumn{2}{|c|}{ 9. Czy w jednostce przenoszono pewne straty bezpośrednio na kapitał własny? } \\
\hline nie, nigdy & 26,1 \\
\hline skutki aktualizacji wyceny środków trwałych & 65,2 \\
\hline skutki aktualizacji wyceny inwestycji długoterminowych & 65,2 \\
\hline koszty reorganizacji i rozszerzenia działania (spółki akcyjne) & 30,4 \\
\hline wpływ zmian rachunkowości & 47,8 \\
\hline skutki błędów podstawowych za poprzednie lata & 39,1 \\
\hline aktualizacja należności & 47,8 \\
\hline inne (jakie? ....) & 8,7 \\
\hline \multicolumn{2}{|c|}{ 10. Czy zdarzyło się jednostce sprzedać lub zastawić aktywa aby poprawić sytuację finansową? } \\
\hline tak & 30,4 \\
\hline tylko faktoring należności & 43,5 \\
\hline nie & 26,1 \\
\hline \multicolumn{2}{|c|}{$\begin{array}{l}\text { 11. Czy w jednostce stosowane było lub jest zabezpieczenie wierzytelności na aktywach obroto- } \\
\text { wych? }\end{array}$} \\
\hline tak & 21,7 \\
\hline nie & 78,3 \\
\hline \multicolumn{2}{|l|}{ 12. Czy jednostka posiada spółki zależne lub podporządkowane? } \\
\hline tak & 60,9 \\
\hline nie & 39,1 \\
\hline \multicolumn{2}{|c|}{$\begin{array}{l}\text { 13. W przypadku pozytywnej odpowiedzi na pytanie } 12 \text {, które jednostki posiadają korzystniej- } \\
\text { szą rentowność }\end{array}$} \\
\hline spółka matka & 13,0 \\
\hline spółki córki & 4,3 \\
\hline co najmniej w jednej spółce córce rentowność jest niższa & 43,5 \\
\hline \multicolumn{2}{|c|}{$\begin{array}{l}\text { 14. W przypadku pozytywnej odpowiedzi na pytanie 12, w których jednostkach szybciej rośnie } \\
\text { zadłużenie? }\end{array}$} \\
\hline w spółce matce & 8,7 \\
\hline w spółkach córkach & 8,7 \\
\hline co najmniej w jednej spółce córce zadłużenie rośnie szybcie & 43,5 \\
\hline
\end{tabular}


cd. tabeli 1

\begin{tabular}{|c|c|}
\hline Wyszczególnienie & Procent \\
\hline \multicolumn{2}{|c|}{ 15. Czy w jednostce zdarzyło się zbyt wysokie wycenienie stopnia wykonania robót? } \\
\hline jednostka nie realizuje długookresowych kontraktów & 47,8 \\
\hline nie, nigdy & 39,1 \\
\hline tak, zdarzyło się & 13,0 \\
\hline \multicolumn{2}{|c|}{$\begin{array}{l}\text { 16. Czy jednostce zdarzyło się sprzedawać produkty lub usługi bez zysku aby zwiększyć sprze- } \\
\text { daż (większe ilości towaru, a nie tylko sprzedaż niechodliwych starych zapasów)? }\end{array}$} \\
\hline tak & 39,1 \\
\hline nie & 56,5 \\
\hline \multicolumn{2}{|c|}{ 17. Czy jednostka przejmuje w pewnych odstępach czasu kolejne firmy? } \\
\hline nie, nigdy & 62,2 \\
\hline od 1 do 5 przejęć & 13,0 \\
\hline od 6 do 10 przejęć & 4,3 \\
\hline powyżej 10 przejęć & 16,1 \\
\hline \multicolumn{2}{|c|}{$\begin{array}{l}\text { 18. Czy w czasie badania przez biegłego rewidenta biegły nakazał poprawę klasyfikacji przy- } \\
\text { chodów lub kosztów? }\end{array}$} \\
\hline nie & 39,1 \\
\hline jednostka nie podlega badaniu audytowemu & 43,5 \\
\hline tak, ale bardzo małe kwoty & 13,0 \\
\hline tak & 4,3 \\
\hline \multicolumn{2}{|c|}{$\begin{array}{l}\text { 19. Czy jednostka prowadzi wzajemną sprzedaż i zakupy z inną jednostką (kupują coś od jed- } \\
\text { nostki i sprzedają jej coś)? }\end{array}$} \\
\hline tak & 34,8 \\
\hline nie & 65,2 \\
\hline \multicolumn{2}{|c|}{ 20. Czy w firmie występowały zapasy, które sprzedano po czasie powyżej roku od ich zakupu? } \\
\hline nie & 39,1 \\
\hline cykl produkcyjny trwa około roku & 8,7 \\
\hline tak & 26,1 \\
\hline tak, ale wartość tych zapasów zawsze spisano w straty & 30,4 \\
\hline w jednostce występują niepłynne zapasy & 21,7 \\
\hline \multicolumn{2}{|c|}{ 21. Czy jednostka była kiedyś oskarżana o przestępstwa karuzelowe? } \\
\hline tak & 8,7 \\
\hline nie & 91,3 \\
\hline \multicolumn{2}{|c|}{ 22. Czy jednostka sprzedała kiedyś aktywa, które potem wtórnie wypożyczyła od nabywcy? } \\
\hline tak & 8,7 \\
\hline nie & 91,3 \\
\hline
\end{tabular}


cd. tabeli 1

\begin{tabular}{|c|c|}
\hline Wyszczególnienie & Procent \\
\hline \multicolumn{2}{|l|}{ 23. Czy firma rozlicza w czasie następujące elementy? } \\
\hline badania rozwojowe & 30,4 \\
\hline remonty & 73,9 \\
\hline inwestycje & 69,6 \\
\hline nadwyżki kosztów nad przychodami & 13,0 \\
\hline koszty produkcji & 0,0 \\
\hline koszty utrzymania majątku & 0,0 \\
\hline inne (jakie? ....) & 0,0 \\
\hline \multicolumn{2}{|l|}{ 24. Czy jednostka zmieniała w ciągu ostatnich 5 lat metodę wyceny zapasów? } \\
\hline tak, wynikało to z wymagań zewnętrznych (granty, zmiany prawa itd.) & 21,7 \\
\hline tak & 13,0 \\
\hline nie & 65,2 \\
\hline \multicolumn{2}{|l|}{ 25. Czy w jednostce zmieniano tempo amortyzacji aktywów? } \\
\hline tak, wynikało to z konieczności korekty błędu & 13,0 \\
\hline tak & 30,4 \\
\hline nie & 56,5 \\
\hline \multicolumn{2}{|l|}{ 26. Czy w złych latach zaniechano lub ograniczono aktualizację wartości aktywów? } \\
\hline tak & 34,8 \\
\hline nie & 65,2 \\
\hline \multicolumn{2}{|l|}{ 27. Czy jednostka posiada w aktywach dobre imię firmy? } \\
\hline tak & 39,1 \\
\hline nie & 60,9 \\
\hline \multicolumn{2}{|l|}{ 28. Czy po przejęciu sprzedano sporą część majątku jednostki przejmowanej? } \\
\hline tak & 17,4 \\
\hline nie & 78,3 \\
\hline \multicolumn{2}{|c|}{$\begin{array}{l}\text { 29. Czy jednostka przyjmowała aporty albo dokonywała aportów rzeczowych w innych jed- } \\
\text { nostkach? }\end{array}$} \\
\hline tak & 34,8 \\
\hline nie & 65,2 \\
\hline \multicolumn{2}{|c|}{$\begin{array}{l}\text { 30. Czy jednostka czerpała korzyści z pomocy innego przedsiębiorstwa w postaci udzielenia } \\
\text { gwarancji, korzystniejszych transakcji, przejęcia na siebie części kosztów? }\end{array}$} \\
\hline tak & 39,1 \\
\hline nie & 60,9 \\
\hline \multicolumn{2}{|c|}{$\begin{array}{l}\text { 31. Czy jednostka zachęcała kiedyś lub udało się zrealizować konwersję części zobowiązań na } \\
\text { akcje? }\end{array}$} \\
\hline tak & 13,0 \\
\hline nie & 87,0 \\
\hline
\end{tabular}


cd. tabeli 1

\begin{tabular}{|l|c|}
\hline \multicolumn{1}{|c|}{ Wyszczególnienie } & Procent \\
\hline 32. Czy w jednostce zdarzyła się konieczność dopłat do kapitału gdyż poniesiono wysoką stratę? \\
\hline \multicolumn{1}{|c|}{ tak, dopłata była skuteczna } & 4,3 \\
\hline tak, ale dopłata nie była skuteczna & 8,7 \\
\hline nie & 87,0 \\
\hline $\begin{array}{l}\text { 33. Czy w jednostce optymalizowano rachunek przepływów pieniężnych, aby wykazywał, jak } \\
\text { najwyższe saldo przepływów na działalności operacyjnej? }\end{array}$ & 0 \\
\hline tak & 100 \\
\hline nie & 26,1 \\
\hline $\begin{array}{l}\text { 34. Czy udziałowcem spółki jest osoba albo jednostka zarejestrowana w krajach szeroko nazy- } \\
\text { wanych rajami podatkowymi? }\end{array}$ & 73,9 \\
\hline tak & 13,0 \\
\hline nie & 87,0 \\
\hline $\begin{array}{l}\text { 35. Czy jednostka lub jej spółki zależne są zarejestrowane w szeroko rozumianych rajach podat- } \\
\text { kowych? }\end{array}$ & 17,4 \\
\hline tak & 82,6 \\
\hline nie
\end{tabular}

Źródło: badania własne.

Jak wynika z tabeli 1 , jedyną techniką, która nie była stosowana przez badane podmioty, było manipulowanie rachunkiem przepływów pieniężnych (częściowo dlatego, że część jednostek go nie sporządzała). Pozostałe techniki stosowały przynajmniej niektóre przedsiębiorstwa. Wśród nich były: renegocjowanie umów zarówno z klientami, jak i dostawcami (część jednostek opóźniała regulowanie faktur bez renegocjacji umowy), wykorzystywanie gwarancji i pomocy innych jednostek (pożyczki, korzystne warunki umów), rozliczanie kosztów w czasie. Ponieważ jednak prawie wszystkie opisane narzędzia są w sposób prawidłowy stosowane $\mathrm{w}$ rachunkowości, to na podstawie ankiety nie tyle można ocenić skalę stosowania window dressingu, co możliwość jego częściowego zastosowania w badanych przedsiębiorstwach. 


\section{Podsumowanie}

Jak to wynika z przedstawionej teorii oraz materiału empirycznego (wyników badań ankietowych), zjawisko modyfikowania obrazu sytuacji finansowej podmiotu gospodarczego jest powszechne. $Z$ uzyskanych badań ankietowych także wynika, że niekiedy granica pomiędzy codziennymi decyzjami finansowymi a window dressingiem i kreatywną rachunkowością jest dość trudna do wyznaczenia.

Opisane w artykule techniki manipulowania wizerunkiem jednostki mogą do pewnego stopnia „upiększyć” sprawozdanie finansowe podmiotu. Wiele z nich to zwykłe czynności rachunkowe, całkowicie dopuszczalne. Większość z nich nie ukryje całkowicie prawdziwej sytuacji jednostki, a najwyżej ją „upiększy” (szczególnie „upiększeniu” może ulec wynik finansowy netto).

Oprócz wzrostu sprzedaży, aktywów i zysków brak rotacji członków zarządu i rady nadzorczej, nieodchodzenie z jednostki najlepszych pracowników i niewyprzedawanie udziałów w jednostce przez insiderów jest sygnałem dobrej sytuacji finansowej jednostki. Inną przesłanką mogą być opinie konkurentów, którzy dzięki spotkaniom i targom znają najnowsze plotki i informacje o jednostce.

Pozytywne saldo operacyjnych przepływów pieniężnych i nieujemny poziom kapitału obrotowego netto za ostatnie 3 lata oraz brak tendencji spadkowej również dobrze świadczy o firmie. Aby ocenić wyniki jednostki, warto usunąć z rachunku zysków i strat jednorazową działalność, która mogłaby w sposób negatywny rzutować na całość [Wyrobek 2012a].

Brak gwałtownego wzrostu zobowiązań długookresowych oraz wartości zabezpieczeń hipotecznych zobowiązań jest również pozytywnym sygnałem. Dobrą opinią powinien cieszyć się zarząd, co można sprawdzić poprzez serwisy pokazujące relacje zawodowe (np. serwis KtoKogo, InfoVeriti) oraz obecne i przeszłe procesy sądowe członków zarządu².

Istotne jest także, aby bezpośrednio w siedzibie firmy zobaczyć, jak ona wygląda oraz jak wyglądają jej oddziały. Bardzo często jest to powiązane z kontaktem z pracownikami lub sąsiadami przedsiębiorstwa i dostarcza wielu cennych informacji (lub ostrzeżeń), które można potem szerzej zbadać. Obecność komornika w firmie może też świadczyć o jej złej kondycji.

${ }^{2}$ Szerzej na temat odpowiedzialności cywilnej członków zarządu spółek kapitałowych i możliwości zabezpieczenia przed tym ryzykiem zob. G. Strupczewski [2013]. 


\section{Literatura}

Fridson M., Alvarez F. [2011], Financial Statement Analysis - a Practitioner's Guide, 4th ed., Wiley, New Jersey.

Gut P. [2006], Kreatywna księgowość a fałszowanie sprawozdań finansowych, C.H. Beck, Warszawa.

Hołda A. [2006], Oszustwa księgowe w praktyce, „Rachunkowość”, nr 9.

Jones M. [2011], Creative Accounting, Fraud and International Accounting Scandals, Wiley, Chichester.

Kaczmarek M. [2010], Oszustwa księgowe - wybrane zagadnienia z teorii i praktyki, http://uoo.univ.szczecin.pl/ marcink/index_pliki/ pliki/publikacje/RK1.pdf (dostęp: 12.04.2010).

Kutera M. [2008], Rola audytu finansowego w wykrywaniu przestepstw gospodarczych, Difin, Warszawa.

Strupczewski G. [2013], Ubezpieczenie odpowiedzialności cywilnej członków władz. spółki kapitałowej, „Zeszyty Naukowe Uniwersytetu Ekonomicznego w Krakowie”, nr 911.

Szychta A. [2012], Dochody całkowite w sprawozdaniach finansowych największych spółek notowanych na GPW w Warszawie, ,Acta Universitatis Lodziensis. Folia Oeconomica", nr 263.

Wąsowski W. [2010a], Kreatywna rachunkowość, czyli fałszowanie sprawozdań finansowych, http://e-rachunkowosc.pl/ artykul.php?view=246 \&part=2 (dostęp: 12.01.2010).

Wąsowski W. [2010b], Kreatywna rachunkowość: fałszowanie sprawozdań finansowych, Difin, Warszawa.

Wyrobek J. [2012a], Ograniczenia analizy wskaźnikowej, „Rachunkowość”, nr 8.

Wyrobek J. [2012b], Zarzadzanie wynikiem finansowym $w$ małych $i$ średnich przedsiebiorstwach w Polsce, ,Zeszyty Naukowe Uniwersytetu Ekonomicznego w Krakowie”, nr 899.

\section{The Impact of "Window Dressing" and Creative Accounting on the True and Fair View of Financial Statements}

The purpose of the paper is to present financial manipulation techniques that were popular in Poland in 2013. The paper is based on interviews with entrepreneurs and a review of previous papers on this subject. The paper also contains a review of selected new legal regulations in Poland intended to counteract and prevent certain types of fraud described in the paper.

Keywords: creative accounting, financial reporting, accounting, window dressing, financial analysis, financial crime. 